Đuro Benić *

Marija Benić Penava**
JEL Classification B1

Pregledni rad

https://doi.org/10.32910/ep.70.1.5

\title{
EKONOMSKA MISAO U ANTIČKOM RIMU
}

Za razliku od antičke Grčke, u antičkom Rimu nije bila razvijena ekonomska misao. Većina ekonomskih pitanja kojim su se bavili pisci i mislioci bila su iz područja poljoprivrede. U antičkom Rimu velika su dostignuća ostvarena na području prava koje je dalo početnu osnovu za dalji razvoj ekonomske misli i analize. $U$ radu se analiziraju neki izravni utjecaji Zakonika XII ploča (Leges duodecim tabularum) na gospodarstvo, te se analiziraju doprinosi osam pisaca i mislioca u razmatranju ekonomskih pitanja: Marka Porcija Katona Starijeg, Tiberija i Gaja Grakho, Marka Terencija Varona, Lucije Junija Moderata Kolumele, Tita Lukrecija Kara, Marka Tulija Cicerona i Lucije Aneja Seneke.

Ključne riječi: ekonomska misao; pravo; patricij; plebejac, rob; gospodarstvo; poljoprivreda

\section{Uvod}

Ekonomska misao u antičkom Rimu nije bila razvijena kao u antičkoj Grčkoj. Rim je gradio imperij na vojnoj snazi i osvajanjima. U društvenoj strukturi Rima

* Dr. sc. Đ. Benić, redoviti profesor u trajnom zvanju, Odjel za ekonomiju i poslovnu ekonomiju, Sveučilište u Dubrovniku (E-mail: dbenic@unidu.hr).

** Dr. sc. M. Benić Penava, docentica, Odjel za ekonomiju i poslovnu ekonomiju, Sveučilište u Dubrovniku (E-mail: marija.benicpenava@gmail.com).

Rad je primljen u uredništvo 05.03.2018. godine, a prihvaćen je za objavu 30.05.2018. 
čisto intelektualni interesi nisu imali prirodno mjesto, pa se aristokracija u Rimu za razliku od aristokracije u Grčkoj svestrano bavila javnim civilnim i vojnim poslovima. ${ }^{1}$ Iako su se ratovima, osvajanjima i širenjem teritorija gospodarski problemi povećavali, doprinosa na području ekonomske misli bilo je jako malo. Do kraja Rimske Republike bilo je dovoljno gospodarskih problema da se o njima bavi veliki broj ekonomista i državnih savjetnika - problemi trgovine, financija, rata, kolonizacije i ropstva samo su neki od njih - a u tom razdoblju pojavio se malo pravog analitičkog rada u ekonomiji. ${ }^{2}$ Većina ekonomskih pitanja koja su privlačila pažnju mislilaca u antičkom Rimu bila su iz područja poljoprivrede. Takva ekonomska literatura uglavnom se bavila praktičnim pitanjima i načelima upravljanja velikim imanjima, a pojedina utvrđivanja činjenica na temelju iskustava bez posebnih analiza nemaju znanstvenu vrijednost. ${ }^{3}$

Istina, mnogi su se autori u antičkom Rimu doticali pojedinih ekonomskih problema i pokazivali su interes za pojedina ekonomska pitanja, ali bez pokušaja sustavnog ekonomskog rezoniranja i sagledavanja funkcioniranja cjelokupnog gospodarstva. Tako je rimski autor Plinije Stariji (23. - 79.) u svom čuvenom djelu enciklopediji Naturalis Historia dao način razmišljanja koji podsjeća na suvremenu ekonomsku teoriju optimizacije kad je napisao: „Treba dobro obrađivati, ali ne previše dobro, jer to donosi gubitke. ${ }^{64}$

${ }^{1}$ Schumpeter, J. A. (1975.). Povijest ekonomske analize. Zagreb: Informator, str. 57.

U pogledu graditeljstva rimska civilizacija bila je najinventivnija i najkreativnija što ju je svijet ikada vidio. U pogledu znanosti ona je bila jedna od najsterilnijih. Rimski se umni sklop oblikovao oko ratovanja kao i upravljanja razvučenim Carstvom. To nije bio umni sklop koji vodi u znanstvenu i industrijsku revoluciju - prema: Aydon, C. (2012.). Povijest čovječanstva. Zagreb: Znanje, str. 76. -77 .

${ }^{2}$ Ekelund, R. B., Hebert, R. F. (1997.). Povijest ekonomske teorije i metode. III. izdanje, Zagreb: MATE, str. 24.

U antičkom Rimu bilo je mnoštvo ekonomskih problema, ali o ekonomiji nije bilo razmatranja. Obrazovanje je bilo književno i retoričko a u nastavnom planu i programu nije bilo znanosti. Doista Rim nije dao veće znanstvenike i znanstvena dostignuća, a Rimljani ni na koji način nisu nastavili napredak koji su postigli Grci. - Spiegel, H. W. (1983). The Growth of Economic Thought. Durham, North Carolina: Duke University Press, str. 39.

Rimljani su izgradili ceste, mostove, akvedukte i spomenike, te sistematizirali i kodificirali zakone, ali nijedno znanstveno otkriće, nijedan novi ili izvorni filozofski sustav, te nijedno izvorno razmišljanje o ekonomskoj problematici nisu ostavili u nasljeđe. - Bell, J. F. (1980). A History of Economic Thought. Second Edition, Huntington, New York: Robert E. Krieger Publishing Company, str. 32.

${ }^{3}$ Rimska pisana djela o poljoprivredi značajna su za ekonomske povijesničare. Bave se načelima upravljanja poljoprivrednim gospodarstvom ili imanjima. Većina preporuka u tim radovima temelje se na zdravom razumu, a ne na znanstvenoj analizi. - Sharma, S. (2010). Reflections on the Philosophical Foundations of Economics. Zagreb: Mikrorad, str. 115.

${ }^{4}$ Sandmo, A. (2011). Economics Evolving: A History of Economic Thought, Princeton and Oxford: Princeton University Press, str. 17. 
Za razliku od područja ekonomije, u antičkom Rimu velika su dostignuća ostvarena na području prava što je donekle i razumljivo imajući na umu nužnost reguliranja javnopravnih i privatnopravnih odnosa u velikoj centraliziranoj državi. Rimsko pravo ima određenu ulogu u povijesti ekonomske misli. ${ }^{5}$ Može se istaći da je rimsko pravo dalo okosnicu na koju je sporo ali sigurno dograđivana ekonomija kasnijeg vremena. ${ }^{6}$

Mnogi se autori slažu oko, kako je ranije istaknuto, skromnog doprinosa Rimljana razvoju ekonomske misli. Rimske ekonomske ideje mogu se skupiti iz tri glavna izvora: (1) nekoliko pisaca o poljoprivredi; (2) pravnici i pisci o pravnim pitanjima; (3) filozofi, a posebice Ciceron i Seneka.?

U ovom radu prvo će se dati kratke napomene iz povijesti antičkog Rima, zatim će se razmotriti neki izravni utjecaji Zakonika XII ploča na gospodarstvo, te, iako u antičkom Rimu nema sustavne ekonomske misli ni analize, istražiti će se i analizirati doprinosi i način gledanja na neka ekonomska pitanja pojedinih pisaca, odnosno mislioca.

${ }^{5}$ Postoji, međutim, jedan veliki rimski doprinos koji je, s obzirom na to da je izvan konvencionalnih granica ekonomije, izmakao konvencionalnoj ekonomskoj raspravi. Bio je to rimski zakon i njegova uloga u privatnom vlasništvu. - Galbraith, J. K. (1995.). Ekonomija u perspektivi. Zagreb: MATE, str. 14. i/ili Galbraith, J. K. (1991). A History of Economics. London: Penguin Books, str. 18.

${ }^{6}$ Ekelund, R. B., Hebert, R. F., isto djelo, str. 24.

Rimskim pravnicima dugujemo definicije - npr. cijene, novca, kupnje i prodaje, različitih vrsta zajmova, dvaju tipova depozita i td. - koje su dale početnu osnovu kasnije analize. Nisu išli dalje od tih početnih osnova pa nije ispravno govoriti o ekonomskoj teoriji Corpus iuris civilis-a - J. A. Schumpeter, isto djelo, str. 59.

Tako se u Corpus iuris civilis-u (Zborniku građanskog prava) u dijelu Institutiones (Institucije) u Knjizi III. kao načelo pravedne trgovine, odnosno pravedne tržišne vrijednosti navodi ,tantum bona valent, quantum vendi possunt" (,dobro vrijedi onoliko za koliko se može prodati“). Vidjeti u: Abdy, J., Walker, B. (Transl.). (1876). The Institutes of Justinian. Book III, Cambridge: The University Press, dostupno na: https://archive.org/stream/institutesofjust00abdyuoft/institutesofjust00abdyuoft_djvu.txt .pristup: 22. 02. 2018.

Corpus iuris civilis Justinijana cara Istočnog Rimskog Carstva nastajao je od 528. do 533. a u njemu je skupljeno cijelo važeće rimsko pravo prilagođeno tom vremenu.

7 Balaglou, C. P. (2012). ,The Tradition of Economic Thought in the Mediterranean World from the Ancient Classical Times Through the Hellenistic Time Until the Byzantine Times and Arab-Islamic World“, u: Backhaus, J. G. (Ed.). Handbook of the History of Economic Thought, New York: Springer, str. 47. 


\section{Kratke napomene iz povijesti antičkog Rima}

Povijest starorimske države obuhvaća tri razdoblja i to Rimsko Kraljevstvo, Rimsku Republiku i Rimsko Carstvo. Rimsko Kraljevstvo trajalo je od 753. godine prije Krista kada je po legendi prvi kralj Romul osnovao Rim nazvavši ga po bratu blizancu Remu kojeg je ubio u borbi za vlast, pa do 509. g. pr. Krista kada nakon posljednjeg rimskog kralja Tarkvinija II. Oholog nastaje Rimska Republika. Vlast u državi preuzima Senat, a postojala je oštra diferencijacija između bogatih patricija i nižeg staleža bespravnih stanovnika Rima plebejaca. Prvobitno su u Senat birani samo patriciji a kasnije i plebejci, a najveću izvršnu neograničenu vlast imao je konzul koji je bio odgovoran i za vrhovno vojno zapovjedništvo. Sustavno se provodila politika osvajanja i širenja teritorija. Velika osvajanja dovodila su stotine tisuća robova čijom je radnom snagom izgrađena infrastruktura od koje su neke građevine ostale do današnjih dana. ${ }^{8}$ Zemlja je bila u vlasništvu rimskih veleposjednika bliskim vojnim i političkim elitama, a obrađivali su je robovi.

Rimsko gospodarstvo temeljilo se na veleposjedima i radu robova i slobodnih poljoprivrednika, te pri kraju Rimskog Carstva kolona koji su bili u sličnom položaju kao kmetovi kasnije u Europi. ${ }^{9}$ Zanatstvo i obrti bili su slabije razvijeni, a kako su osnova Rimskog Carstva bili rat i osvajanja malo se izvozilo a skoro sve uvozilo. Razvoj gradova (Rim je u prvom stoljeću imao blizu milijun stanovnika) i povećana potrošnja doveli su do nesrazmjera između poljoprivredne proizvodnje i potražnje, pa je nedovoljna proizvodnja bila pokrivena uvozom žitarica iz Egipta, Sicilije i Sardinije. Pojačana je trgovačka aktivnost izgradnjom velike luke u Ostiji. Pompeji su bili najveći centar za prikupljanje i sortiranje vinogradarskih proizvo-

${ }^{8}$ U drugoj polovini 2. st. pr. Kr. pojedini ratovi donosili su često po 150 do 200000 i više robova, a na tržištima se prodavalo na desetine tisuća robova gdje su često robovi bili na puno višem stupnju obrazovanja i kulture od robovlasnika - Rozenberg, D. (1949.). Istorija političke ekonomije, prijevod s ruskog, Beograd, str. 17.

Najveće tržnice robova bile su na egejskim otocima Delosu i Rodosu, te gradska tržnica u Rimu. Delos je 166. g. pr. Kr. proglašen slobodnom lukom i postao je jedno od glavnih tržnica robova na kojem se skupljalo po 10000 robova dnevno i svi bi do večeri bili prodani - Mesihović, S. (2015.). Orbis Romanvs. Sarajevo, str. 473.

Na Delosu se prodavalo i do 100000 robova dnevno - Kale, E. (1990.). Povijest civilizacija. VI. izdanje, Zagreb: Školska knjiga, str. 48.

Robovi su u Rimu bili osnovna snaga društva, za vrijeme pada grada Epira 167. g. pr. Kr. bilo je prodato 150000 robova - Marković, M. (1984.). Istorija ekonomske misli. I. knjiga, Titograd: Univerzitetska riječ, str. 33.

${ }^{9}$ Kolonima su zemljoposjednici davali manje površine zemlje u zakup. Zakup je plaćan u novcu, udjelom u urodu ili radom. Koloni su potjecali od lokalnog stanovništva i oslobođenih robova. U odnosu na zemljoposjednika bili su pravno neovisni i slobodni, a ugovor o zakupu zaključivao se na određeno vrijeme i bio je raskidiv. 
da. Uz pomorski i kopneni razvijao se prijevoz rijekama (posebice duž toka rijeke Po) i jezerima. Trgovina je bila razgranata ne samo u Italiji već i u provincijama sve do skandinavskih zemalja, preko Balkana do južne Rusije i karavanskim putovima do središnje Azije i Arabije.

Značajan razvoj ostvario je sektor građevinarstva. Izgrađene su monumetalne građevine sa specijaliziranim radnicima u pojedinim poslovima. Tako je Kolosej sagrađen za samo pet godina. Usko povezano s razvojem građevinarstva raslo je opekarstvo posebice nakon požara 64. godine i obnove Rima, te vađenje kamena. Na Cezarovu inicijativu mramor iz Carrare počeo se prvo upotrebljavati u Rimu, da bi se njegova upotreba proširila po svim gradovima u Italiji. Izgrađene su brojne luke, ceste, mostovi, akvedukti i druge javne građevine javnim radovima s velikim sredstvima na državnoj i lokalnoj razini. Javni radovi financirani su novcem iz državne riznice i carske blagajne stimulitrane priljevom bogatstva iz osvojenih područja. Razvoj gospodarstva u prvom stoljeću olakšala je široka upotreba novca koju je omogućavala velika dostupnost zlata iz rudnika u vlasništvu države. Razgranati su bili novčarski poslovi, odnosno kreditiranje - lihvarenje. ${ }^{10}$

Položaj robova pogoršavao se jer s prestankom velikih osvajačkih ratova nije bilo priljeva robovske radne snage kao prije, a sve veće robovsko iskorištavanje dovodilo je do ustanaka robova od kojih je veliki ustanak bio od 73. do 71. g. pr. Kr. pod vodstvom Spartaka roba iz Tracije gladijatora koji je okupio vojsku od 40 000 robova. Uz to, na političkom planu nakon dugotrajnih sukoba i buna, zahtjeva za agrarnom reformom i preraspodjelom vlasti narod je uspio dobiti učešće u vlasti u obliku narodnih tribuna i narodnih skupština iako su i dalje o svim bitnim pitanjima odlučivali patriciji preko Senata.

S druge strane vojni zapovjednici su privatne interese suprotstavljali volji Senata i narodnih skupština što je dovelo do građanskih ratova. ${ }^{11}$ Nakon drugog građanskog rata Cezar postaje jedini vladar, a nakon atentata na Cezara u Senatu 44. g. pr. Kr. i trećeg rimskog građanskog rata Marko Antonije i Oktavijan dijele vlast tako da Oktavijan vlada zapadnim a Marko Antonije istočnim dijelom rimskog teritorija. Nakon bitke kod Akcija 31. g. pr. Kr. Oktavijan nakon povlačenja Marka Antonija i Kleopatre u Egipat postaje samostalni vladar, preuzima sve ovlasti republikanskih institucija i 27. g. pr. Kr. kao Oktavijan August osniva Rimsko Carstvo.

${ }^{10}$ O gospodarstvu u Rimskom Carstvu opširnije vidite u: Cravetto, E., Goldstein, I. (ur.). (2007.). Povijest. 5. knjiga, Zagreb: Europapress holding, str. 89. - 159.

${ }^{11}$ U građanskim ratovima izgubio se smisao za demokraciju. Širi se korupcija, rastu bogatstva pojedinaca, grade se veliki amfiteatri u kojima se odigravaju krvave gladijatorske igre u kojim nastupaju i po 10000 gladijatora i do 600 lavova da zabave sirotinju koja gledajući smrti zaboravlja svoj jadni život - Filipović, V., „Uvod: Lukrecijev materijalistički životni nazor“, u: Kar, T. L. (1952.). O prirodi. II. izdanje, Zagreb: Matica hrvatska, str. 14. 
Rimsko Carstvo bilo je jedna od najvećih država u povijesti, a trajalo je do pada Zapadnog Rimskog Carstva 476. godine kada je germanski vojskovođa Odoakar svrgnuo s prijestolja posljednjeg rimskog cara Romula Augustula. Istočno Rimsko Carstvo - Bizant i dalje je postojalo smanjujući se sve do 1453. godine kad su Turci osvojili Konstantinopol. Rimsko carstvo obuhvaćalo je države na Sredozemlju, sjevernu Afriku, Hispaniju, Galiju i Britaniju. Najveću ekspanziju Rimsko Carstvo imalo je pod carom Trajanom (uz ostalo osvojeni su Armenija, Mezopotamija i Babilon) tako da je početkom 2. stoljeća obuhvaćalo oko 5 milijuna $\mathrm{km}^{2}$ i 88 milijuna stanovnika. Nakon sustavnog progona kršćana kršćanstvo je 313. godine priznato kao zakonita vjera.

Poslije cara Marka Aurelija koji je vladao od 161. do 180. godine počinje postupno propadanje Carstva. Sve su češći bili upadi barbara na teritorij Carstva, a stalni upadi germanskih, slavenskih i drugih plemena uz unutarnje sve teže socijalno stanje i sukobe između vojnih zapovjednika oslabilo je Carstvo koje nije izdržalo prodore Gota i Huna. Kao što je navedeno germanski vojskovođa Odoakar svrgnuo je 476. godine posljednjeg rimskog cara i proglasio se rimskim kraljem kojim činom je Zapadno Rimsko Carstvo prestalo postojati. ${ }^{12}$

\section{Zakonik XII ploča: neki izravni utjecaji na gospodarstvo}

Rimsko pravo stvoreno je na temeljima koji su postavljeni Zakonikom XII ploča. Zakoni su jedan od izvora rimskog prava i to: Kraljevski zakoni, Zakonik XII ploča i 11 zakona donijetih nakon Zakonika XII ploča. ${ }^{13}$

Zakonodavnu funkciju u doba Rimske Republike i početka Rimskog Carstva vršile su narodne skupštine: kurijatska, centurijatska i tributska. Rimski su se zakoni zasnivali na načelu osobnosti, pa je zakon (lat. lex) obvezivao rimskog građanina bez obzira gdje se on nalazio a nije pripadnika drugog naroda (stranca) pa i u slučaju kad je prebivao u Rimu.

Zbog sukoba između plebejaca i patricija u Rimu a u cilju donošenja Zakonika povjerenstvo od tri člana boravilo je u Grčkoj proučavajući čuvene Solonove zakone, a po povratku osnovana je magistratura od deset članova koja je nakon jedno-

${ }^{12}$ O usponu i padu Rimskog Carstva vidite u: van Beest, G. D. R. et al. (1974.). Velika ilustrirana povijest svijeta. Rijeka: Otokar Keršovani, Šesti svezak, str. 2465. - 2542.; Sedmi svezak, str. 2961. - 3023. i Aydon, C., isto djelo, str. 75. - 81.

${ }^{13}$ Ostali izvori su: Pretorski edikti, Mišljenja Senata, Carske konstitucije, Zakon o citiranju i Kodifikacije. Pregled izvora rimskog prava vidite u: Romac, A. (1973.). Izvori rimskog prava. Zagreb: Informator, str. 13. - 137. 
godišnjeg rada 451. g. pr. Kr. dostavila deset ploča zakona koji su na centurijatskim skupštinama prihvaćene. Sljedeće godine su dodane još dvije ploče tako da je dobijen Zakonik XII ploča (lat. Leges duodecim tabularum). Tekst Zakonika bio je napisan na mjedenim pločama i izložen na Forumu sve do 390. g. pr. Kr. kad su nakon galskog napada nestale u požaru. Iako tekst Zakonika XII ploča nije sačuvan, sadržaj Zakonika ostao je poznat prema prijepisima pa se često u literaturi navode pozivi na njegove odredbe pa i citati (koji po procjeni čine oko jedne trećine prvobitnog teksta Zakonika).

Sadržajno, u tekstu Zakonika zastupljene gotovo sve grane tada poznatog prava: civilno privatno pravo, javno pravo, kaznene norme uključujući privatne delikte, sakralno pravo i neke pravne poslove. ${ }^{14}$ Zakonik XII ploča predstavlja kodifikaciju rimskog običajnog prava, a njegovo donošenje značilo je određen stupanj pravne sigurnosti i uvođenje u načelu jednakosti građana pred zakonom. ${ }^{15}$

Postoje odredbe Zakonika koje su imale izravan utjecaj na ekonomsku misao $^{16}$ i posebice na gospodarstvo, a neke od njih su sljedeće.

Prema Zakoniku, Ploča III., dužniku je dopušten rok od 30 dana kako bi mogao prikupiti potrebna sredstva za vraćanje duga. Ako dug ne vrati vode ga na sud, a ako ne ispuni presudu ili ako pred sudom nitko ne garantira za vraćanje duga dužnika vjerovnik ga vodi sa sobom, okiva ga okovima ne težim od 15 funti a može i lakšim. Ako dužnik hoće može dobijati hranu od srodnika ili prijatelja, a ako ne onaj tko ga drži okovanog treba mu dati svakog dana funtu brašna a može

${ }^{14}$ Romac, A., „Rimsko zakonodavstvo i Zakonik XII ploča“, u: Zakonik dvanaest ploča. (1994.). Prevod, uvod i komentar: Ante Romac, Zagreb: Latina et Graeca, str. 64.

Neposrednu ekonomsku važnost imale su doktrine što su ih rimski pravnici razradili za reguliranje ekonomskih odnosa. One su podupirale gotovo neograničeno pravo privatnog vlasništva i osiguravale slobodu ugovora - Roll, E. (1956.). Povijest ekonomske misli. Zagreb: Kultura, str. 26.

Mnoge značajne ekonomske ideje artikulirane su u rimskom trgovačkom pravu. - Backhouse, R. E. (2002). The Penguin History of Economics. London: Penguin Books, str. 26.

${ }^{15}$ Rimsko je pravo sve građane štitilo od samovolje i jamčilo im je pravnu sigurnost. Nikoga se nije smjelo kazniti bez provedenog sudskog postupka i bez dokaza o krivnji. To danas smatramo uobičajenim, ali je za tadašnje doba bilo revolucionarno. Rimsko je pravo postalo temeljem mnogih pravnih sustava diljem svijeta. - Mai, M. (2004.). Kratka povijest svijeta. Zagreb: Mozaik knjiga, str. 39.

U moderniziranom obliku rimsko pravo je postalo pravom više od tri četvrtine civiliziranog svijeta. Razvoj i utjecaj rimskog prava od posebnog su značaja za studiranje ekonomske misli. Bell, J. F., isto djelo, str. 28. - 29.

${ }^{16}$ Općenito se može reći da utjecaj rimskog prava na ekonomsku misao srednjovjekovnih skolastika nije bio ograničen samo pitanjima o cijeni, vrijednosti, vlasništvu i dohotku, već je bio značajan i u oblikovanju njihove percepcije o prirodi novca. - Prema: Gordon, B. (1975). Economic Analysis before Adam Smith. London and Basingstoke: Macmillan Press, str. 133.

O utjecaju rimskog prava na različita područja ekonomije vidite u: isto djelo, str. 122. - 140. 
i više. Ako se dužnik i vjerovnik ne nagode dužnici su držani u okovima 60 dana. Kroz to vrijeme oni su u tri uzastopna sajmena dana izvođeni pred pretora na komicij gdje je objavljivano na koji su iznos duga osuđeni. Trećeg sajmenog dana kažnjavani su smrtnom kaznom ili prodavani u ropstvo na drugu stranu Tibera. ${ }^{17}$

Ploča V. propisuje da ako netko umre bez oporuke a nema najbližeg nasljednika (sin, kćer, supruga, unuk, unuka), nasljedstvo pripada najbližem agnatu (rođaku po muškoj liniji). Ako nema agnata nasljedstvo pripada gentilima (krvnim srodnicima istog imena koji potječu od zajedničkog pretka). ${ }^{18}$

Isto tako, prema Ploči V. ,ako je netko duševno bolestan, neka agnati i gentili upravljaju njime i njegovom imovinom“. ${ }^{19}$

$\mathrm{O}$ odnosima među susjedima u pogledu dodirnih zemljišta u Zakoniku se propisuje da ako se drvo sa susjedovog zemljišta, povijeno vjetrom nađe na zemljištu njegova susjeda može se pravovaljano tražiti (tužiti) da drvo bude uklonjeno. ${ }^{20}$ Isto tako Zakonik je određivao da se mogu prikupljati plodovi sa susjedovog zemljišta koji padnu na zemljište njegovog susjeda. ${ }^{21}$

O aktu kupoprodaje Zakonik propisuje sljedeće. „Prodane i predane stvari postaju vlasništvo kupca samo onda kada je on prodavaocu isplatio cijenu ili mu na (neki) drugi način dao osiguranje, kao na primjer određivanjem poruka ili davanjem zaloga;“‘22

Zakonik XII ploča zabranjivao je svakome uzimanje kamata viših od jedne dvanaestine. Većina mišljenja je da se kamata odnosi na $1 / 12$ mjesečno, odnosno $100 \%$ godišnje. ${ }^{23}$

I na kraju, sudac pravovaljano određen za suđenje kažnjavao se smrtnom kaznom ako bi se utvrdilo da je primio novac zbog spora koji je trebao presuditi. ${ }^{24}$

${ }^{17}$ Zakonik dvanaest ploča. ..., Ploča III., 1. - 5., str. 83.

„Trećeg sajmenog dana neka se sasjeku na dijelove. Ako više ili manje odsijeku, neće se smatrati krivima“" (Isto djelo, Ploča III., 6., str. 85.). Ova odredba Zakonika je sporna jer prema nekim mišljenjima ne radi se o stvarnom ubijanju i podjeli tijela dužnika. Međutim, činjenica je da je ovrha poduzimana na osobi dužnika te da se imovinska ovrha prodajom imovine dužnika uvela u Rimu tek kasnije, a da je postupak ovrhe na osobi dužnika bio vrlo surov i da je postojala mogućnost ubijanja dužnika.

${ }^{18}$ Isto djelo, Ploča V., 4. - 5., str. 85. - 87.

19 Isto djelo, Ploča V., 7 a., str. 87.

${ }^{20}$ Isto djelo, PločaVII., 9b., str. 91.

${ }^{21}$ Isto djelo, Ploča VII., 10., str. 91.

${ }^{22}$ Isto djelo, Ploča VII., 11., str. 91.

${ }^{23}$ Isto djelo, Ploča VIII., 18a., str. 97. i 138.

${ }^{24}$ Isto djelo, Ploča IX., 3., str. 99. 


\section{Doprinosi pojedinih pisaca i mislioca u razmatranju ekonomskih pitanja}

Od pisaca i mislioca koji su, između ostalih pitanja i problema kojim su se bavili, pisali i raspravljali o pojedinim ekonomskim pitanjima, u nastavku se razmatraju i analiziraju doprinosi osmorice najznačajnijih.

Marko Porcije Katon Stariji (lat. Marcus Porcius Cato Maior) 234.- 149. g. pr. Kr.

Marko Porcije Katon bio je rimski vojskovođa, veliki zemljoposjednik, političar i pisac. Sudjelovao je u ratu protiv Hanibala, ugušio je ustanak u Hispaniji. Uporno je tražio da se sjevernoafrička Kartaga (u današnjem Tunisu) razori završavajući svaki govor u Senatu riječima Ceterum ceuseo Carthaginem esse delendam (Uostalom mislim da Kartagu treba razoriti), što su Rimljani i učinili 146 g. pr. Kr., tri godine nakon Katonove smrti. ${ }^{25}$ Njegovo najznačajnije djelo je historiografsko djelo Podrijetla (lat. Origines) koje je u sedam knjiga obuhvćalo rimsku povijest od osnutka Rima do Katonova doba ali nije sačuvano. Drugo njegovo djelo O poljodjelstvu (lat. De Agricultura) u cjelosti je sačuvano i to je nastarije sačuvano prozno djelo rimske književnosti. ${ }^{26}$

U djelu $O$ poljodjelstvu detaljno obrazlaže pitanje upravljanja kućanstvom i imanjem na tragu onog što je razmatrao u antičkoj Grčkoj Ksenofont u djelu Ekonomija.

Katon zagovara proizvodnju za vlastite potrebe, a ne za tržište na kojem se mogu prodavati samo viškovi proizvodnje te kupovati neophodna dobra koja se ne proizvode na imanju. Upućuje na to da izgradnju gazdinstva treba poduzeti kad pojedinac navrši 36 godina. ${ }^{27}$ Ako je moguće poljoprivredno gazdinstvo treba biti na podnožju planine, okrenuta na južnu stranu s dosta vode, blizu većeg grada, na moru, plovnoj rijeci ili dobroj prometnici, a treba izabrati mjesto gdje gazdinstva nisu često mijenjala vlasnike. ${ }^{28} \mathrm{U}$ cilju ostvarenja većih prihoda treba prodavati stare i bolesne robove ${ }^{29}$, a kupovati mlade koje je lakše obučiti, hraniti ih i odijevati prema efikasnosti njihovog rada i tako ih poticati na veću angažiranost u radu.

${ }^{25}$ Tada Sicilija i sva područja u dotadašnjem kartaškom posjedu (između ostalog Sardinija, Korzika, Španjolska i dijelovi sjeverne Afrike) postaju rimske provincije. - Mai, M., isto djelo, str. 40.

${ }^{26}$ Dostupno na internetu na latinskom i engleskom: LacusCurtius.Cato: De Agricultura (www.penelope.uchicago.edu) .

${ }^{27}$ Cato, M., De Agricultura. (www.penelope.uchicago.edu/Thayer/E/Roman/Texts/Cato/ De_Agricultura/A*.html), 3., str. 11., pristup: 16.02.2018.

${ }^{28}$ Isto djelo, 1., str. 5.

${ }^{29}$ Isto djelo, 2., str. 9. 
Katon je hvalio mala poljoprivredna gazdinstva a o velikim je imao nepovoljno mišljenje. ${ }^{30}$ Propisuje potrebno ljudstvo, stoku i opremu za pojedine vrste gazdinstva. Tako je za maslinik od 240 jugera $^{31}$ potreban nadglednik, domaćica, pet radnika, tri vodiča volova, jedan svinjar, jedan gonič mula i jedan pastir (13 ljudi) ${ }^{32}$, a za vinograd od 100 jugera nadglednik, domaćica, deset radnika, kočijaš, mazgar, svinjar i radnik sakupljač grana (16 ljudi). ${ }^{33}$ Katon daje uputstvo za uzgajanje pojedinih vrsta kultura (kupus je najbolje povrće), a o volovima i drugoj stoci treba se brinuti s najvećom pažnjom. ${ }^{34}$

Katonovo djelo zadojeno je duhom upornog rada, najštedljivijeg gospodarenja i neprekaljenog starorimskog puritanizma. ${ }^{35}$

\section{Marko Terencije Varon (lat. Marcus Terentius Varro) 116. - 27. g. pr. Kr.}

Uz Katona potrebno je ukratko navesti i doprinose još dva pisca o poljoprivredi i to Marka Terencija Varona i Lucija Moderata Kolumela.

Marko Terencije Varon obnašao je različite državne dužnosti, ali se posvetio znanstvenom radu. Bio je vrlo cijenjen i nazivan „najučeniji Rimljanin“. Napisao je 74 djela u oko 620 knjiga iz područja književnosti, povijesti, prirodnih znanosti i filozofije od koji je u cjelosti sačuvano samo djelo $O$ poljoprivredi (lat. Res Rusticae) u tri knjige. ${ }^{36}$ Piše o zadatcima velikih latifundija bez izravnih praktičnih uputstava i preporuka kao što je činio Katon. ${ }^{37} \mathrm{U}$ prvoj knjizi razlaže proble-

30 Backhaus, J. G., isto djelo, str. 47.

31 juger $=240 \times 120$ rimskih stopa $=2524 \mathrm{~m}^{2} ; 240$ jugera $=60,6$ ha

32 Cato, M., De Agricultura. ..., 10., str. 23. (uz tri para volova, tri magarca za nošenje i jednog za okretanje mlina, te sto ovaca)

33 Isto djelo, 11., str. 25.

34 Kad razlaže problematiku odnosa između korisnosti i moralne ispravnosti, te uspoređivanja korisnosti i uobičajenog postavljanja prihoda od gradskih poslova iznad prihoda od seoskih poslova, Ciceron navodi poznate riječi Katona Starijeg. Kad ga se pitalo što donosi najviše prihoda na imanju odgovorio je: „Marljivo uzgajati stoku“. Na pitanje što je nakon toga kao drugo isplativo rekao je: „Dovoljno marljivo uzgajati stoku“. Kao treće: Ne baš marljivo uzgajati stoku“. Četvrto: „Orati“. $\mathrm{Na}$ to je onaj koji mu je postavljao pitanja rekao: „A kako bi bilo posuđivati novac s kamatama?“ Katon mu odvrati: „A kako bi bilo ubijati ljude?“ - Ciceron, M. T. (2006.). O dužnostima. Zagreb: Nova Akropola, str. 137.

35 Lunaček, V. (2004.). Povijest ekonomskih doktrina. Zagreb: Dom i svijet / Ekonomski fakultet, str. 75 .

${ }^{36}$ Dostupno na internetu na latinskom i engleskom: Varro: De Re Rustica, www.penelope. uchicago.edu .

37 Ipak napominje npr. da je vrlo bitno odabrati što i gdje uzgajati imajući na umu što susjed uzgaja jer od toga ovisi ostvarenje profita. „Ako u blizini granice raste hrast lužnjak nije dobro posaditi masline jer se hrast i maslina po prirodi ne slažu pa će maslina dati ne samo manji urod već će se i savijati prema zemlji, a isti je slučaj s vinovom lozom kada je posađena u blizini kupusa. Kao kad 
matiku seoskog imanja, zgrada i potrebne opreme na imanju. ${ }^{38}$ Druga je posvećena stočarstvu (uzgoj krava i ovaca), a treća sitnim životinjama.

Posebice ističe svoj negativan stav prema zemljoposjednicima koji žive u gradovima i tako zanemaruju svoju ulogu u upravljanju imanjem, dok robove svrstava u oruđa koja govore. Naime, u razmatranju oruđa, odnosno sredstava za obrađivanje zemljišta Varon navodi da neki vrše podjelu sredstava na ljude i pamagala ljudima bez kojih se ne mogu obrađivati zemljišta, dok drugi razlikuju tri vrste sredstava: artikulirana, neartikulirana i nijema. Artikulirana sredstva su robovi (oruđe koje govori), neartikulirano oruđe je stoka, dok nijema oruđa obuhvaćaju alat i vozila. ${ }^{39}$ Kako su robovi dio kapitala, u nezdravim i močvarnim krajevima preporuča se zaposlenje plaćenih, slobodnih radnika umjesto robova, jer smrt plaćenog radnika ne znači gubitak kapitala kako je to slučaj kod robova. ${ }^{40}$

Varon posebno naglašava da je osobito važno da su nadzornici iskusni u poljoprivrednim poslovima. Nadzornik ne smije samo davati zapovijedi nego i sudjelovati u radu, tako da bi podređeni mogli slijediti njegov primjer, a također i shvatiti da postoji dobar razlog zašto je on iznad njih - činjenica da je nadmoćniji od njih u znanju. ${ }^{41}$

je u pitanju hrast, tako i brojna velika stabla oraha čini grancu imanja sterilnom.“ - Varro, M. T., De Re Rustica. Book I, 16, str. 223., dostupno na: http://penelope.uchicago.edu/Thayer/E/Roman/Texts/ Varro/de_Re_Rustica/1*.html, pristup 16.02. 2018.

${ }^{38}$ Tako ističe da ,mnoge pogreške proizlaze iz dimenzioniranja imanja pa neke zgrade imaju manju a neke veću dimenziju od potrebnih, od kojih su obje štetne za imovinu i njen prihod. Prevelike zgrade su skupe za izgradnju i koštaju mnogo za održavanje, a ako su manje od potrebitih proizvodi obično propadaju. Nema sumnje da veći vinski podrum treba izgraditi na imanju gdje postoji vinograd a veće hambare ako se uzgajaju žitarice.“ - Isto djelo, Book I, 11, str. 209.

Uz navedeno Varon ističe i sljedeće.

„Imanje je nesumnjivo profitabilnije ako su zgrade napravljene shodno štedljivosti starijih ljudu a ne shodno modernom luksuzu, jer su prve izgrađene tako da odgovaraju veličini usjeva, a druge tako da zadovolje razuzdani luksuz. U ovo vrijeme pohvalno je imanje sa zgradama ako ima dobru kuhinju, prostrane staje i podrume za vino i ulje proporcionalno veličini imanja s podom koji ima kosinu u spremnik, jer često ... kod mladih vina posude pucaju od fermentiranja mošta." - Isto djelo, Book I, 13, str. 215.

${ }^{39}$ Isto djelo, Book I, 17, str. 225.

${ }^{40}$ Lunaček, V., isto djelo, str. 75.

Varon naglašava i sljedeće. „Moje je mišljenje da je više isplativo obrađivati manje plodna zemljišta s unajmljenim radnicima; pa čak i na plodnim zemljištima s njima je isplativo obavljati složenije poslove kao što su uskladištenje proizvoda nakon berbe i žetve.“- Varro, M. T., isto djelo, Book I, 17, str. 225.

${ }^{41}$ Isto djelo, Book I, 17, str. 227. 


\section{Lucije Junije Moderat Kolumela (lat. Lucius Junius Moderatus Columella) 4. - 70. g.}

Lucije Junije Moderat Kolumela bio je pisac o poljoprivredi rodom iz Gadesa u Hispaniji (današnjeg Cadiza u Španjolskoj). Na svojim imanjima u Italiji stekao je iskustvo u praktičnom vođenju gazdinstava, te je na temu poljoprivrede napisao više djela od kojih je u potpunosti sačuvano njegovo glavno djelo $O$ seoskim poslovima (lat. De Re Rustica) u 12 knjiga. ${ }^{42} \mathrm{U}$ njima razmatra problematiku obrađivanja polja, stočarstva i veterinarstva.

To djelo je po metodi i sadržaju najbolje djelo rimske književnosti te struke, napisano kao pravi znanstveni priručnik agronomije. 1. i 2. knjiga obrađuju ratarstvo, 3. - 5. vinogradarstvo i voćarstvo, 6. - 9. stočarstvo, peradarstvo i pčelarstvo, a 11. i 12. sadrže upute o raznim dužnostima i poslovima poljoprivrednika. Pisana je na temelju starije grčke i rimske literature, kao i temeljem Kolumelinog iskustva koje je prikupio u Šanjolskoj, Italiji i Aziji. Prema Kolumeli poljodjelstvo zauzima prvo i počasno mjesto među svim ljudskim zanimanjima. Na početku prve knjige Kolumela naglašava da „onaj koji se posvećuje poljoprivredi treba shvatiti da mora zatražiti pomoć u najosnovnijim resursima: znanju o poljoprivredi, načinu plaćanja troškova i volji za obavljanje posla. ... Najbolje obrađenu zemlju imat će oni koji imaju znanje, opremu i volju za raditi. ${ }^{، 43}$ Smatra da je plodnost zemlje vječna, neiscrpiva i nepromjenjiva uz stalno, racionalno i primjereno gnojenje. ${ }^{44}$ On je prvi rimski pisac koji osuđuje osvajačke ratove. Rad robova u poljodjelstvu smatra jednim od glavnih razloga propadanja poljodjelstva i seljačkog staleža jer robovi lošim i nerazumnim radom uništavaju plodove zemlje. ${ }^{45}$

${ }^{42}$ Prve četiri knjige na engleskom jeziku dostupne su na: www.penelope.uchicago.edu .

Svih 12 knjiga na latinskom jeziku: Columella, L. J. M., De Re Rustica Libri XII. dostupno je na: www.thelatinlibrary.com/columella.html , pristup: 18. 02. 2018.

${ }^{43}$ Columella, De Re Rustica. Book I, 1, str. 27., dostupno na:http://penelope.uchicago.edu/ Thayer/E/Roman/Texts/Columella/de_Re_Rustica/1*.html, pristup: 24. 02. 2018.

${ }^{44}, \ldots$ pogrešno je uvjerenje da je zemlja, majka svih stvari poput žene koja je istrošena starošću nesposobna nositi potomke ... . Možemo dobiti veće žetve ako zemlju oporavimo čestim, pravodobnim i umjerenim gnojidbama.“- Isto djelo, Book II, 1, str. 109.

${ }^{45}$ Lunaček, V., isto djelo, str. 75. - 76.

Prema Kolumeli, u pogledu robova vrlo je bitno na koje ih dužnosti postaviti i koje im zadatke dodijeliti. „Stoga je na početku moj savjet ne imenovati za nadzornike robove koji su fizički zgodni, a zasigurno ne iz redova onih koji su se bavili pohotnim zaposlenjima u gradu. Treba izabrati čovjeka koji je radom od ranog djetinstva otvrdnuo i koji ima iskustvo. Ako takva osoba nije dostupna treba izabrati između onih koji su robovali teškim radom. ... Takav bi trebao biti srednje dobi, snažne tjelesne građe, obučen radom u poljoprivredi ili barem vrlo radišan tako da može spremnije učiti.“ Columella, De Re Rustica. Book I, 8, str. 85.

„Nadglednik se mora brinuti o opremi i željeznim alatima, popravljati ga i skladištiti duplo od broja kojeg trebaju robovi, tako neće biti potrebno zaduživati se kod susjeda; gubitak u radu robova viši je od cijene takvih alata.“ - Isto djelo, Book I, 8, str. 89. 
Uočavajući nisku proizvodnost robovskog rada, Kolumela je protiv velikih latifundija te zagovara mala imanja i to podjelom latifundija slobodnim kolonima čiji bi rad bio proizvodniji. ${ }^{46} \mathrm{Na}$ taj način proizvodila bi se dovoljna količina nužnih proizvoda koji se tada ne bi uvozili a čemu se Kolumela žestoko protivio. ${ }^{47}$ Tako Kolumela razvija jednu vrstu teorije stabilnosti malog zemljoposjeda što je za njegovo vrijeme bilo napredno. Kroz njegovo pisanje nazire se raspadanje robovlasničkog uređenja i početak feudalizma.

\section{Tiberije (163. - 132. g. pr. Kr.) i Gaj (154. - 122. g. pr. Kr.) Grakho (lat. Tiberius Sempronius Gracchus i Gaius Sempronius Gracchus)}

Osvajačka politika Rima i ratovi koje su vodili daleko od Italije a posebice stoljeće ratovanja s Kartagom (gradom - državom u Sjevernoj Africi u današnjem Tunisu) i pobjede 146. g. pr. Kr., te osvajanje grčkih područja imalo je za posljedicu slabljenje snage, krizu i polagano propadanje Rimske Republike. Naime, kako Rim nije imao profesionalnu vojsku, svi muškarci sposobni za borbu bili su vojnici. Zbog dugotrajnih ratova najviše su stradali sitni zemljoposjednici u selima čija su imanja propadala, a zbog preživljavanja prodavali su ih velikim zemljoposjednicima koji su se sve više bogatili. Ratovi su doveli do velikog broja ratnih zarobljenika koji su postajali robovi i bili su najvećim dijelom radna snaga na velikim latifundijama što je smanjivalo potražnju za domaćom radnom snagom, odnosno bivšim vlasnicima malih posjeda i članovima njihovih obitelji. Oni su odlazili u Rim i postajali gradska sirotinja. Time se temeljna podjela na patricije i plebejce posstupno gubila a sve izraženija postajala je podjela stanovnika Rima na vrlo bogate i vrlo siromašne koji su živjeli od državne pomoći, milodara i rijetkih zarada.

Braća Grakho potjecali su iz ugledne aristokratske obitelji. Njihova majka Kornelija bila je kćer velikog vojskovođe Publija Kornelija Scipiona Afričkog Starijeg. Udajom za plebejca sinovi Tiberije i Gaj s obzirom na očevo podrijetlo

${ }^{46} \mathrm{Kad}$ je priljev robovske radne snage bio vrlo nizak zemljoposjednici su dijelili svoje latifundije na dva dijela: jedan (lat. villa) obrađivali su sami, a drugi (lat. vici) dijeljen je na manje parcele koje su obrađivali koloni. - Jakšić, M., Praščević, A. (2007.). Istorija ekonomije, Beograd: Centar za izdavačku delatnost Ekonomskog fakulteta u Beogradu, str. 7.

${ }^{47}$ Treba imati na umu da je Rim bio prisiljen redovito uvoziti barem 150.000 tona žita godišnje od 1. st. pr. Kr. do 3. stoljeća (uz opskrbu daleko razmještene rimske vojske). - Finley, M. I. (2011.). Antička ekonomija. Zagreb: MATE, str. 199.

U svezi sa gore navedenim, kad je 58. g. pr. Kr. Rim započeo svoju dugu povijest besplatnog raspodjeljivanja žita (i poslije drugih živežnih namirnica), nastanjeni građani (ali nitko drugi) imali su pravo na udjele bez obzira na imovinsko stanje. To se načelo održalo sve dok Severi (Severska dinastija, op.a.), u ranom trećem stoljeću, nisu pretvorili raspodjelu hrane u pomoć za rimsku sirotinju, bez obzira na politički status, što je označilo efektivni kraj građanstva kao formalnog statusa u carstvu. - Isto djelo, str. 170. 
imali su status plebejaca. Obojica su bili veliki govornici, štovatelji grčke filozofije, književnosti ali i atenske demokracije o čemu su saznanja dobivali od grčkih odgojitelja i učitelja. Njihova želja i cilj bio je poboljšati položaj rimskog puka zemljišnim reformama koje bi ograničile moć veleposjednika i veličinu njihovih posjeda na 500 jugera državne zemlje - lat. ager publicus - koja se povećavala osvajačkim ratovima. Pozivali su se na Licinio - Sextianov zakon iz 367. g. pr. Kr. prema kojem je pojedinac mogao imati najviše 500 jugera državne zemlje, odnosno 126,2 ha što se u praksi nije poštivalo. Višak iznad tog limita podijelio bi se siromašnim čime bi porastao broj malih posjednika koji bi dobili zemlju s nasljednim pravom ali bez prava prodaje tako stečene imovine.

Tiberije je postao plebejski, odnosno narodni, pučki tribun 133. g. pr. Kr. Prema Tiberijevom prijedlogu zakona pojedinac iz fonda ager publicus može imati najviše do 500 jugera zemlje. U slučaju da ima dva sina svaki od njih mogao je posjedovati još po 250 jugera, ali ukupna veličina zemljišta po jednoj porodici nije mogla biti viša od 1000 jugera. Onim kojim se oduzima višak zemljišta treba isplatiti naknadu za uložena sredstva u zemljište koje im se oduzima. Realizacija zakona bila bi pod nadzorom agrarne komisije od tri člana koja bi bila stalna državna institucija, a čiji bi se sastav mijenjao svake godine. ${ }^{48}$

Tiberije je svojim govorima ukazivao na bijedu naroda, tražio uspostavu neotuđivih minimalnih seljačkih posjeda od 30 jugara i pomoć siromašnim seljacima za nabavku zemljišnog inventara. ${ }^{49}$ Pod pritiskom javnog mišljenja Senat je protiv svoje volje izglasao Tiberijev prijedlog o podjeli zemlje, ali je pravio poteškoće pri realizaciji tog zakona. Tiberija Grakha ubili su drvenim kijačama (batinama sa zadebljanjem na jednom kraju) optimati (konzervativna frakcija u Senatu koja je bila suprotstavljena popularima) na Kapitoliju za vrijeme izborne kampanje, a mrtvo tijelo bacili su u rijeku Tiber.

Tiberijev brat Gaj Grakho nastavio je aktivnosti svog brata. Bio je izabran za pučkog tribuna (124. - 123. g. pr. Kr.), a predlagao je niz socijalno - političkih reformi, rješenje problema nezaposlenosti izgradnjom cesta kroz cijelu Italiju, a isto tako tražio je i demokratizaciju izbornog prava. Normalno, došao je u sukob sa senatorima. Dali su ga ubiti, a s njim je ubijeno i više od tisuću njegovih pri-

${ }^{48}$ Prema: Mesihović, S. (2011.). Revolucije stare Helade i Rimske Republike. Sarajevo: Filozofski fakultet u Sarajevu, str. 295.

${ }^{49} \mathrm{U}$ jednom govoru siromašnim plebejcima ističe sljedeće. „Divlje životinje koje borave u Italiji, imaju svoje spilje; svaka od njih zna svoje ležište, svoje skrovište. Samo ljudi, koji se bore i umiru za Italiju, ne mogu ni na što da računaju osim na zrak i svijetlo; bez kuća i sjedišta, moraju oni sa ženama i djecom da lutaju zemljom. ... Samo za raskoš i bogatstva drugih moraju oni da prolijevaju krv i umiru. Zovu se gospodari svijeta, a ni jednu grudu zemlje ne mogu nazvati svojim vlasništvom.“ - Plutarh, Biografija Tiberija Grakha, prema: Filipović, V., isto djelo, str. 12. - 13. 
stalica. ${ }^{50}$ Tijekom građanskih ratova i diktature Kornelija Sule 82. - 79. g. pr. Kr. odbacile su se sve Grakhove socijalne reforme, donesen je zakon kojim se umanjio utjecaj plebejskih tribuna koji nisu mogli donijeti nikakav zakon bez odobrenja Senata, a za porotnike imenovani su samo senatori čime je poništen zakon koji je donio Gaj Grakho.

Usprkos činjenici da je nakon vojnih osvajanja i širenja teritorija gospodarstvo Rima propadalo, da su ekonomski problemi poticali političke krize, te da su braća Grakho nastojala svojim djelovanjem stabilizirati gospodarstvo Rima i riješiti probleme u kojim se našla Rimska Republika, interesantno je mišljenje o njihovom djelovanju slavnog Cicerona koji je pripadao redu optimata (što treba imati na umu). „Tiberije Grakho, Publijev sin, bit će hvaljen tako dugo dok god bude živjelo sjećanje na Rim, dok djela njegovih sinova vrli muževi nisu odobravali ni za njihova života, a nakon smrti ubrajalo ih se među one koje se smaklo s pravom. ${ }^{\text {j51 }}$

Ipak ne može se reći da je djelovanje braće Grakho ostalo bez učinka, iako je povratak na male jednoobiteljske posjede postajao sve teži zbog novih vrsta kultura i proizvodnih tehnika, mogućih samo na velikim posjedima s odgovarajućim ulaganjima. Dodjelom obrađene zemlje u mnogim se djelovima Italije nekoliko desetaka tisuća ljudi bez posjeda pretvorilo u maloposjednike. Uz to, reformsko djelovanje braće Grakho vratilo je snagu pučkom tribunatu koji je izgubio snagu integriranjem u ustavni sustav ali je pokazao da po potrebi može ponovno dobiti na značaju u izvornoj funkciji instrumenta borbe protiv ustavnih interesa (August ga je u temeljima svog principata uvrstio u sustav ovlasti). Isto tako, posljedica reformi braće Grakho općenito se osjećala u italijanskom gospodarstvu koje je nakon stagancije ušlo u ciklus ekspanzije zahvaljujući između ostalog stvaranju

${ }^{50}$ Septumulej iz lacijskog grada Anagnije nakon smrti Gaja Grakha odsjekao mu je glavu i odnio je konzulu Luciju Opimiju koji je za nju obećao toliko zlata koliko teži. - Ciceron, M. T. (2002.). O govorniku. Zagreb: Matica hrvatska, str. 202., bilješka 141.

Podjelu građana u dva tabora Senat, međutim, nije uspio spriječiti. Politička je svakodnevnica u sljedećih sedamdeset godina postala nasilje i građanski rat. - Prema: Mai, M., isto djelo, str. 41.

${ }^{51}$ Ciceron, M. T. (2006.) O dužnostima. ..., str. 112. Na istoj stranici u bilješci 101. navodi se komentar da su reforme braće Grakho bile zapravo vrsta onodobne „nacionalizacije dobara“. Činjenica je da su svojom djelatnošću u Rimu izazvali velike nerede, a posljedica toga osjećala se sve do Suline diktature pa i kasnije.

Uz navedeno, ističući da su vrlo rječiti ljudi nanijeli više štete nego pomoći državi, Ciceron za braću Grakho navodi da iako su bili ,... rječiti i za govorenje opremljeni što uz pomoć prirode, što uz pomoć obrazovanja, kad su preuzeli državu koja je bila u punom cvatu zahvaljujući savjetima njihovog oca (Tiberije Grakho Stariji, op.a.) i oružju njihovog djeda (Scipion Afrički Stariji, op.a.) razmrvili su državu jer ih je vodila ta slavna ... rječitost.“ - Ciceron, M. T. (2002.). O govorniku. ..., I - 38, knjiga 1. § 38, str. 43. 
mnoštva novih poljoprivrednih posjeda, sredstvima koja su u njih uložena, te javnim radovima koji su posebno potaknuti primjenom Zakona lex frumentaria. Taj Zakon je donesen na inicijativu Gaja Grakha kojim je utvrđena mjesečna distribucija žita po garantiranim cijenama, a zahtijevao je novu organizaciju usluga, izgradnju središta za prikupljanje žita, popravak cesta, prijevoz i skladišta. ${ }^{52}$

\section{Tit Lukrecije Kar (lat. Titus Lucretius Carus) 99. - 55. pr. Kr.}

Tit Lukrecije Kar, rimski filozof i pjesnik, bio je vrlo osjetljiv i povučen čovjek koji je veći dio života proveo u Rimu ne učestvujući u javnosti. O njegovom životu malo se pouzdano zna osim hipotetičkih podataka i različitih interpretacija ovisno o tome da li su ih pisali njegovi ideološki protivnici ili sljedbenici. Napisao je filozofski spjev $O$ prirodi (lat. De rerum natura) u kojem približava grčke filozofske ideje Rimljanima, te u kojem materijalističkim tumačenjem (kako sam ističe pod velikim utjecajem grčkog filozofa materijalističke i hedonističke orijentiranosti Epikura, 341. - 270. g. pr. Kr.) daje enciklopediju svog vremena. U djelu razmatra različite teme iz područja prirodnih znanosti, medicine, psihologije, filozofije, povijesti, ontologije (odnosno opće metafizike u kojoj proučava biće kao takvo), antropologije i dr. Svojim materijalizmom suprotstavlja se tradicionalnim zabludama i konzervativnim običajima, a njegova filozofija nije samo teorija nego i praksa, odnosno svojevrsna uputa u traganju za istinom i srećom. Prema njegovom shvaćanju ,zlatni vijek“ nastupit će tek u budućnosti. Pri tome pozornost usmjerava prema budućnosti, a ne prema analizi prošlih zbivanja. Time je on predvijesnik i ideolog feudalizacije društva. ${ }^{53}$

Razmatrajući društvene probleme Lukrecije Kar uzroke siromaštva nalazi u tome što oni koji su ekonomski jači teže povećanju bogatstva gdje se bez obzira na upotrebljena sredstva nastoje domoći većeg bogatstva. ${ }^{54}$ Prema Karu lakomost

52 Prema: Cravetto, E., Goldstein I. (ur.), isto djelo, 4. knjiga, str. 35. - 37.

Zahtjevi koje su isticali braća Grakho pripadaju najrevolucionarnijim zahtjevima tog doba. Međutim, ti zahtjevi ne diraju u robovlasništvo kao društveno-ekonomski sustav. Štoviše, ti zahtjevi su, objektivno, išli ka stvaranju jakog društvenog oslonca tom sustavu kroz slobodno seljaštvo koje bi raspolagalo određenim zemljišnim vlasništvom - Prema: Šoškić, B. (1988.). Ravoj i osnove savremene ekonomske misli. Beograd: Savremena administracija, str. 14.

${ }^{53}$ Legradić, R. (1975.). Historija ekonomske teorije: otkrivanje zakona vrijednosti. Osijek: Štampa, str. 43.

${ }^{54}$, ,.. lijući krv, imutak hoće da steknu,

Pohlepno bogatstvo zgrću, gomilajući pokolj na pokolj;““

Kar, T. L. (1952.). O prirodi. ..., , III., 70 - 71, str. 139. 
i težnja za moći uzroci su društvenih nevolja, dok istovremeno siromaštvo potiče ljude na pobune i suprotstavljanje postojećim zakonima. ${ }^{55}$

U petom pjevanju „Kozmologija i povijest kulture“ Lukrecije Kar analizira razvoj društva kroz nastanak i razvoj kulture. Razvoj društva je neprekidan proces. ${ }^{56} \mathrm{U}$ koncept evolucijskog pravolinijskog razvoja Kar uklapa svoju cikličku teoriju razvoja u kojoj pojedini dijelovi kulture nastaju, rastu i razvijaju se da bi zatim ostarjeli i propali. ${ }^{57}$

Stvaralački ljudski rad uvjetuje napredak i razvoj koji vodi ugodnijem i kvalitetnijem životu. Tako Lukrecije Kar objašnjava različite stupnjeve razvoja od kamenog, preko bakrenog do željeznog doba. Također ukazuje na stupnjeve civilizacija gdje je niži stupanj stočarstvo a viši ratarstvo, koje počinje voćarstvom da bi se zatim širile plodne oranice a smanjivale šume. ${ }^{58}$

Na taj način, razvoj se temelji na napretku koji je rezultat stvaralačkog ljudskog rada, a tijekom vremena pojedini dijelovi kulture stare i propadaju dok drugi nastaju i ciklički se razvijaju. ${ }^{59}$

55 „Konačno lakomost slijepa za častima, požuda uz to

Tjera siromašne ljude, da granice prelaze prava ..."

Isto djelo, III., 59 - 60, str. 138.

„Naime, siromaštvo gorko, pa sramotan gotovo prezir

Izgleda skoro nespojiv sa ugodnim stalnim životom;““

Isto djelo, III., 65 - 66, str. 139.

56 „Starost promijeni, naime, prirodu cijelog svijeta,

Te iz jednog stanja sve u drugo prelazi stalno.“

Isto djelo, V., 828 - 829, str. 235.

57 „Naime zbog starosti jedno dok vene i slabije biva,

Dotle uzraste nam drugo i vrijednost dobiva svoju.

Tako prirodu, dakle cijelog promijeni svijeta

Starost, te ... Zemlja iz jednog sveđ u drugo prelazi stanje:

Ne stvara više, što j' mogla, a stvara, što prije nij’ mogla“"

Isto djelo, V., 832 - 836, str. 235. - 236

58 „Pomalo šume sve više u brda da uzmiču, stanu

Siliti, kako li dalje bi polja imali plodna;““

Isto djelo, V., 1370 - 1371, str. 251.

59 „Promjena vremena tako i vrijednost stvarima mijenja:

Što bi nekad u cijeni, to izgubi kasnije vrijednost,

Kako na njegovo mjesto iz tame bi izašlo drugo.“

Isto djelo, V., 1276 - 1278, str. 248. 


\section{Marko Tulije Ciceron (lat. Marcus Tullius Cicero) 106. - 43. g. pr. Kr.}

Marko Tulije Ciceron bio je državnik, odvjetnik, filozof, politički teoretičar i najveći rimski govornik. Rođen je u Arpinu u obitelji pripadnika viteškog staleža. Školovao se u Rimu i Grčkoj. Odvjetništvo i govorništvo usmjerilo ga je prema politici tako da je 75. g. pr. Kr. bio kvestor na Siciliji, 69. g. pr. Kr. edil, 66. g. pr. Kr. pretor, te 63. g. pr. Kr. konzul. Kao konzul stekao je slavu otkrivajući Katalininu urotu protiv rimske države, a kažnjavajući sudionike bez sudskog procesa bio je u progonstvu godinu dana u Solunu i Draču. U građanskom ratu između Cezara i Pompeja, iako je pripadao redu optimata, bio je pristalica Pompeja što mu je Cezar oprostio. Nije bio upleten u Cezarovo ubojstvo 44. g. pr. Kr. Svojim govorima, žestokim filipikama, započeo je obračun s Markom Antonijem otvarajući put Cezarovu nećaku Oktavijanu Augustu. Nakon sklapanja trijumvirata Oktavijana, Antonija i Lepida 43. g. pr. Kr. plaćenici Antonija ubili su Cicerona u njegovoj vili u Kajeti, a njegova glava i desna ruka bile su izložene na govorničkom podiju Foruma gdje je on kratko prije toga držao žestoke govore protiv Antonija. ${ }^{60}$

Ciceron je upoznao Rim s različitim školama grčke filozofije služeći se ostavštinom Epikura, Platona i Aristotela, te je stvorio temelje zapadne, odnosno latinske filozofske terminologije. ${ }^{61} \mathrm{U} 14$. i 15 . stoljeću u razdoblju humanizma svestrano su proučavana djela Cicerona, a posebice njegov stil i jezik.

Kod Kara nalazimo ne samo ideju da je razvitak društva neprekidan proces, već i ideju da se taj razvitak osniva na napretku materijalnih proizvodnih snaga. Po tim idejama Kar bi se mogao smatrati, iako vrlo dalekim, prethodnikom historijskog materijalizma. - Prema: Blagojević, O. (1983.). Ekonomske doktrine. IV. izdanje, Beograd: Privredni pregled, str. 49. - 50.

${ }^{60}$ O Ciceronovom životu opširnije vidite: Milanović, Z., „Uvod - život i djelo“, u: Ciceron, M. T. (2007.). Lelije o prijateljstvu. Zagreb: CID - NOVA, str. 11. - 24.

${ }^{61}$ Ciceron, Seneka i drugi rimski filozofi nisu stvorili nikakav nov filozofski smjer. Oni su ili eklektici ili su sljedbenici pojedinih mlađih grčkih filozofskih škola, većinom stoika i skeptika Lunaček, V., isto djelo, str. 72. 
U etici bio je sljedbenik stoika, moralnost navodi kao najviše dobro smatrajući da ništa ne može biti uistinu korisno ako nije i moralno ispravno. ${ }^{62}$ Smatra da je u osnovi svega ljudski rad. ${ }^{63}$

Prema Ciceronu najbolje je državno uređenje izložio u svoje vrijeme najutjecajniji Rimljanin Scipion Afrički Mlađi (185. - 129. g. pr. Kr.), cenzor i konzul, osvajač Kartage, veliki protivnik reformi Tiberija Grakha. ${ }^{64}$ Na pitanje da li vlast treba pripadati kralju, optimatima ili narodu Scipion tvrdi da svako od tih uređenja ima dobre i loše strane, a da bi najbolje uređenje bio skladan spoj svih triju oblika jer bi takva država bila najčvršća u kojoj nitko ne bi imao razloge za prevrat. ${ }^{65}$

Od čisto ekonomskih pitanja koje je razmatrao posebno je interesantan Ciceronov stav prema trgovini i zanatstvu, odnosno prema časnim i nečasnim poslovima. Za nečasne se, prema njemu, drže oni poslovi koji izazivaju odbojnost, kao ubiranje poreza i lihva, te najamnički poslovi gdje se ne plaća umijeće nego

${ }^{62}$ Stoicizam je pravac, odnosno škola antičke filozofije koju je 308. g. pr. Kr. osnovao grčko fenički filozof Zenon iz Kitija. Bila je jedna od najutjecajnijih i najdugotrajnijih škola - ukinuo ju je bizantski car Justinijan 529. godine. U antičkoj Grčkoj i Rimskom Carstvu pristalice je imala među obrazovanom elitom. Bavila se etikom, promovirala kao najznačajnije vrline razumnost, pravednost i umjerenost s načelom „Živi u skladu s prirodom i vlastitim razumom“.

Stoicizam je rado prihvaćen u Rimu. Hrabrost, postojanost i umjerenost bile su veoma cijenjene vrline u Rimskom carstvu (Vejnović, N. (1966.). Historija filozofije. II. izdanje, Zagreb: Školska knjiga, str. 26.). Tako je koncept razumnosti u mnogim odredbama rimskog trgovačkog prava imao podrijetlo u idejama stoicizma (Backhouse, R. E., isto djelo, str. 26.). Filozofija stoicizma u Rimu dobila je svoj najdublji izraz u Meditacijama rimskog cara Marka Aurelija (Rima, I. H. (2001). Development of Economic Analysis. Sixth Edition, London: Routledge, str. 9.). Aurelijevo jedino djelo zbirka misli Samome sebi prevođeno i kao Meditacije i/ili Misli nastalo je na carevim vojnim pohodima (vidite: Aurelije, M. (2017.). Meditacije. Zagreb: Planetopija).

O stoicizmu opširnije vidite u Hirschberger, J. (1995.). Mala povijest filozofije. Zagreb: Školska knjiga, str. 42. - 44., a o rimskom stoicizmu u: Bošnjak, B. (1983.). Filozofija od Aristotela do renesanse. IV. izdanje, Zagreb: Matica hrvatska, str. 30. - 32.

${ }^{63}$ Bez ljudskog rada ne bi moglo biti ni brige za zdravlje, ni plovidbe, ni poljodjelstva, ni ubiranja i čuvanja plodova, ni svega ostalog. Ne bi također bilo ni izvoza onoga čime obilujemo, ni uvoza onoga što nam nedostaje, da se ljudi nisu opremili za to prilagođenim sredstvima - Ciceron, M. T. (2006.). O dužnostima. ..., str. 96.

${ }^{64}$ Bio je oženjen Sempronijom sestrom Gaja Grakha. Godine 129. pr. Kr. pridobio je Senat da obustavi rad komisije za dodjelu zemlje, a nedugo poslije toga, dan prije nego što je trebao održati govor protiv populara, pod nerazjašnjenim okolnostima je umro. Nađen je mrtav u svojoj kući, a sumnjalo se u nasilnu smrt iza koje je stajala njegova supruga Sempronija.

${ }^{65}$ „Kad je tomu tako, po mojem mišljenju od onih triju poredaka daleko najveću prednost zaslužuje kraljevski, a od kraljevskog će biti bolji onaj koji je ravnomjerno sastavljen od triju osnovnih državnih poredaka. Poželjno je naime da u državi bude nešto istaknuto i kraljevsko, nešto prepušteno i ostavljeno autoritetu prvaka, a nešto zadržano za sud i volju mnoštva ... Ne postoji naime razlog prevratu tamo gdje svatko čvrsto stoji na svojem stupnju i nema kamo opasti i strmoglaviti se.“ - Cicero, M. T. (1995.). Libri Politici. Zagreb: DEMETRA, Svezak prvi; Država, Knjiga prva, $\S 69$, str. 76. i 78. 
rad. Svi obrtnici nalaze se u području jednostavnih umijeća jer radionica ne može imati u sebi ništa plemenito. ${ }^{66}$

Nasuprot grčkim filozofima Ksenofontu, Platonu i Aristotelu koji su osuđivali trgovinu na veliko koja je poduzimana u cilju ostvarenja velikih dobiti, a neophodnu trgovinu na malo su odobravali, Ciceron ima negativan stav prema trgovini na malo koju smatra nečasnom, a pozitivan stav ima prema trgovini na veliko. ${ }^{67}$ Naglašava da je od svih djelatnosti koje donose dobit najbolje i najčasnije poljodjelstvo. ${ }^{68}$

\section{Lucije Anej Seneka (lat. Lucius Annaeus Seneca) 4. g. pr. Kr. - 65. g.}

Lucije Anej Seneka nazivan Seneka Mlađi (lat. Seneca Minor) rođen je u rimskoj Kordubi (danas Cordoba, Španjolska). Od djetinstva pokazivao je nadarenost, a pod utjecajem njegovih učitelja stoika i pitagorejaca tog doba stekao je široku naobrazbu. U Rimu je studirao retoriku i filozofiju. Postao je vrlo cijenjeni pravnik, govornik, filozof i jedan od najznamenitijih pisaca starog vijeka.

Bio je financijski magnat, jedan od nautjecajnijih rimskih državnika, političar i plodan pisac. Svi problemi kojim se bavio zapravo su trajni problemi zapadne civilizacije; jednostavno ne postoji ništa bitno što bi se u suvremenoj zbilji razlikovalo od Senekina iznimno slojevitog zapažanja, kako ljudske osobnosti koja je uvijek ista, tako i vlastite epohe, koja je problemski donekle univerzalna. ${ }^{69}$

Kao član Senata došao je u nemilost cara Kaligule i zatim Klaudija, te je prognan na Korziku. U izgnanstvu se posvetio učenju i u tom razdoblju napisao je

${ }^{66}$ Za razliku od zanimanja za koja je potrebna veća pamet i iz kojih proizlazi veća korist, kao što su medicina, arhitektura ili humanističke znanosti - Ciceron, M. T. (2006.). O dužnostima. ... str. 83. -84 .

${ }^{67}$ Ovakav stav prema trgovini objašnjava se činjenicom da je u to doba baš trgovina na veliko bila jedan od načina bogaćenja rimske plutokracije čije je interese Ciceron zastupao. - Prema: Blagojević, O., isto djelo, str. 49.

68 „Trgovinu na malo tako treba smatrati nečasnom, ali ako je bogata i na veliko, te mnoštvo roba donosi sa svih strana, razdjeljujući ih na mnoga područja i bez varanja, onda je ne treba koriti previše, štoviše može se čak i potpuno opravdano hvaliti ako donosi veliku korist i zadovoljava velike potrebe, kao kad se dobra preko mora dovoze u luke, a iz luka dalje na kopno i posjede. Od svih pak stvari iz kojih se postiže dobit ništa nije bolje od poljodjelstva, ništa tako isplativo ni tako ugodno i čovjeka dostojno“ - Ciceron, M. T. (2006.). O dužnostima. ..., str. 84.

Inače u ekonomskoj misli antičkog Rima odnos prema trgovini bio je dvojak. Odobravala se trgovina koja je služila moći i bogaćenju patricija. Osuđivala se trgovina kojojm se jačao novi sloj bogataša iz redova plebejaca, koji je stvarao bogatstvo u novčanom obliku i osporavao vlast rodovskom plemstvu - Sabolović, D. (1972.). Historija političke ekonomije. Zagreb: Informator, str. 19.

${ }^{69}$ Milanović, Z., „Uvod“, u: Seneka, L. A. (2007.). Dijalozi, Zagreb: Nova Akropola, str. 22. -23 . 
neka od svojih najznačajnijih filozofskih djela (O dobročinstvima - De beneficiis, O blagosti - De clementia, Dijalozi - Dialogi i dr.). Čuvena su njegova 124 sačuvana pisma, odnosno filozofski eseji iz područja praktične etike (Moralna pisma Luciliju - Epistulae morales ad Lucilum).

Iz prognonstva vratio se nakon osam godina, 49. godine, i postao je učitelj jedanaestogodišnjem Neronu, a poslije savjetnik kad je Neron sa 17 godina postao car. U prvih pet godina uz maloljetnog Nerona de facto Seneka upravlja državom i to vrlo uspješno. Međutim, Neron izlazi iz Senekinog utjecaja, preuzima svu vlast i djeluje kao bolesno ambiciozna i svirepa osoba koja je pogubila mnoge ugledne Rimljane i članove svoje obitelji. Iako se Seneka povukao s dvora kako bi se posvetio književnosti optužen je za urotu protiv cara. Prisiljen je zajedno sa suprugom Paulinom izvršiti samoubojstvo 65. godine pred svojim učenicima i prijateljima (kako je zapisao rimski povjesničar Publije Kornelije Tacit).

Seneka je djelovao u vrijeme okrutne vladavine te je nastojao potaknuti suvremenike na moralan život. Upravo je etika težište njegove filozofije. Polazi od čovjekove moralne slabosti, te tvrdi da pojedinac mora u prvom redu održavati moralnu strogost prema sebi kako bi mogao biti blag i sućutan prema drugim. Vrlo suptilno, izravno i jasno govori odnosno piše o potrebi usavršavanja karaktera i uređenja vlastitog života. ${ }^{70}$ Senekino djelo (pjesme, tragedije, satire, moralno-filozofski spisi) stoljećima je imalo veliki utjecaj na europsku književnost.

U Moralnim pismima Seneka se dotiće i nekih ekonomskih tema - primjerice štednje ${ }^{71}$ duga, ${ }^{72}$ te između ostalog pravovremenog ispravnog ekonomskog ponašanja. ${ }^{73}$ Međutim, potrebno je posebno istaći da je Seneka bio prvi antički filozof koji je smatrao da ropstvo nije prirodno.

Naime, razmatrajući problematiku ropstva i robova Seneka ističe tezu suprotnu Aristotelovoj. Još prije Aristotela u antičkom svijetu postojala je klasifikacija oruđa za rad na: (1) nijema oruđa za rad - alati, stvari; (2) polunijema oruđa za rad s neartikuliranim glasovima - životinje i (3) oruđa za rad koja govore - robovi. ${ }^{74}$ Aristotel, smatrajući da je suprotnost između umnog i fizičkog rada prirodna, tvrdi da su po prirodi neki ljudi stvoreni za robove (uz robove koji su u ropstvo došli po

${ }^{70}$ „Čovjek još uvijek nije dobar ako je bolji od najgorih“ - Seneka, L. A. (2013.). Moralna pisma Luciliju. Svezak prvi, Zagreb: Demetra, str. 415.

${ }^{71}$ Citirajući Hezioda Seneka kaže: „Kasno je štedjeti kad dođe do dna bačve“. Na najdonjem se dijelu ne nalazi, dakako, samo najmanje, već i ono najgore. - Isto djelo, str. 5.

${ }^{72}$ „Mali dug čini dužnika, a velik neprijatelja“ - Isto djelo, str. 87.

73 ,... kako je lijepo završiti život prije smrti, pa zatim bezbrižno pričekati preostali dio svog vremena i ništa uvjeravati sebe, makar imaš sretan život, da on nije sretniji zato što je dulji“ - Isto djelo, str. 149.

${ }^{74}$ Rozenberg, D., isto djelo, str. 16. Kao što je već navedeno i prema Marku Terenciju Varonu ista je podjela oruđa za rad, robovi su samo dio kapitala, oruđa koja govore. 
položaju kao što su ratni zarobljenici ${ }^{75}$ ). Seneka ističe da su po prirodi ljudi jedna$\mathrm{ki}^{76}$ Društveni odnosi čine ljude nejednakim i otud smatra da ropstvo nije prirodno. Iako Seneka ideju jednakosti ljudi tumači u etičkom i religioznom smislu, ona je imala značajnu ulogu u razvoju ekonomskih ideja.

\section{Zaključak}

Suprotno od dostignuća s područja prava, ekonomska misao u antičkom Rimu nije bila razvijena kao u antičkoj Grčkoj. Rimsko pravo ima određenu ulogu u povijesti ekonomske misli jer je dalo okosnicu na koju je sporo ali sigurno dograđivana ekonomija u kasnijem razdoblju. Zakonik XII ploča predstavlja kodifikaciju rimskog običajnog prava čije je donošenje značilo određen stupanj pravne sigurnosti i uvođenje u načelu jednakosti građana pred zakonom, a neke odrebe Zakonika imale su izravan utjecaj na gospodarstvo.

Od pisaca i mislioca koji su se bavili i pisali o pojedinim ekonomskim pitanjima moguće je izdvojiti one koji su raspravljali o problemima poljoprivrede i filozofe koji su u raspravama doticali pojedina pitanja i probleme iz područja ekonomije, odnosno gospodarstva.

Marko Porcije Katon detaljno je obrazlagao problematiku upravljanja kućanstvom i imanjem na tragu onog što je u antičkoj Grčkoj razmatrao Ksenofont. Marko Terencije Varon pisao je o zadatcima velikih latifundija bez izravnih praktičnih savjeta i preporuka kao što je činio Katon. Lucije Junije Moderat Kolumela napisao je najznačajnije djelo iz područja poljoprivrede u kojem istupa protiv velikih latifundija. Zagovara mala imanja i tako razvija jednu vrstu teorije stabilnosti malog zemljoposjeda.

Braća Tiberije i Gaj Grakho nastojali su poboljšati položaj rimskog puka zemljišnim reformama koje bi ograničile moć veleposjednika, a podjelom zemlje siromašnim potaći male posjednike i time stabilizirati gospodarstvo Rima koje je

${ }^{75}$ Poslije zabrane prodaje domorodaca Grka u roblje zbog dugova, Grci su samo kao ratni zarobljenici mogli postati robovi, pa zbog toga Aristotel razlikuje robove po prirodi i robove po položaju koji su u ratu dospjeli u ropstvo - Legradić, R., isto djelo, str. 35.

${ }^{76}$ „Robovi su ipak ljudi ... i zato se smijem onima koji smatraju da je sramno ručati zajedno sa svojim robom... ne posjedujemo ih kao neprijatelje, ali ih činimo neprijateljima..." - Seneka, L. A. (2013.). Moralna pisma Lucijiju. ..., str. 193.

„Sjeti se samo da je onaj čovjek kojeg ti nazivaš svojim robom rođen iz istog sjemena, da živi pod istim nebom, da jednako diše, jednako živi, jednako umire! ... Živi s nižim od sebe onako kako bi htio da viši od tebe živi s tobom!“ - Isto djelo, str. 195. 
propadalo, te dijelom riješiti probleme u kojim se našla Rimska Republika. Završili su tragično, a sve njihove reforme su odbačene.

Tit Lukrecije Kar rimski pjesnik i filozof svojim materijalizmom suprotstavlja se tradicionalnim zabludama i konzervativnim običajima. Analizira razvoj društva u kojem se razvoj temelji na napretku koji je rezultat stvaralačkog ljudskog rada. Marko Tulije Ciceron državnik, filozof i najveći rimski govornik nasuprot grčkim filozofima Ksenofontu, Platonu i Aristotelu, koji su osuđivali trgovinu na veliko poduzimanu u cilju ostvarenja velikih dobiti, ima negativan stav prema trgovini na malo koju smatra nečasnom a pozitivan stav prema trgovini na veliko. Naglašava da je od svih djelatnosti koje donose dobit najbolje i najčasnije poljodjelstvo. Lucije Anej Seneka jedan od vodećih pisaca starog vijeka bio je prvi antički filozof koji je smatrao da ropstvo nije prirodno, odnosno da su ljudi po prirodi jednaki. Iako Seneka ideju jednakosti ljudi tumači u etičkom i religioznom smislu, ona je imala značajnu ulogu u razvoju ekonomskih ideja.

\section{Literatura:}

Abdy, J., Walker, B. (Transl.). (1876). The Institutes of Justinian. Book III, Cambridge: The University Press. Dostupno na: https://archive.org/stream/institutesofjust00abdyuoft/institutesofjust00abdyuoft_djvu.txt

Aurelije, M. (2017.). Meditacije. Zagreb: Planetopija

Aydon, C. (2012.). Povijest čovječanstva. Zagreb: Znanje

Backhouse, R. E. (2002). The Penguin History of Economics. London: Penguin Books

Balaglou, C. P. (2012). „The Tradition of Economic Thought in the Mediterranean World from the Ancient Classical Times Through the Hellenistic Time Until the Byzantine Times and Arab-Islamic World“, u: Backhaus, J. G. (Ed.). Handbook of the History of Economic Thought, New York: Springer

Bell, J. F. (1980). A History of Economic Thought. Second Edition, Huntington, New York: Robert E. Krieger Publishing Company

Blagojević, O. (1983.). Ekonomske doktrine. IV. izdanje, Beograd: Privredni pregled

Bošnjak, B. (1983.). Filozofija od Aristotela do renesanse. IV. izdanje, Zagreb: Matica Hrvatska

Cato, M., De Agricultura. Dostupno na: www.penelope.uchicago.edu/Thayer/E/Roman/ Texts/Cato/De_Agricultura/A*.html

Cicero, M. T. (1995.). Libri Politici. Zagreb: DEMETRA

Ciceron, M. T. (2007.). Lelije o prijateljstvu. Zagreb: CID - NOVA

Ciceron, M. T. (2002.). O govorniku. Zagreb: Matica hrvatska 
Ciceron, M. T. (2006.). O dužnostima. Zagreb: Nova Akropola

Columella, L. J. M., De Re Rustica. Dostupno na: http://penelope.uchicago.edu/Thayer/E/ Roman/Texts/Columella/de_Re_Rustica/1*.html

Columella, L. J. M., De Re Rustica Libri XII. Dostupno na: www.thelatinlibrary.com/ columella.html

Cravetto, E., Goldstein, I. (ur.). (2007.). Povijest. Zagreb: Europapress holding

Ekelund, R. B., Hebert, R. F. (1997.). Povijest ekonomske teorije i metode. III. izdanje, Zagreb: MATE

Finley, M. I. (2011.). Antička ekonomija. Zagreb: MATE

Galbraith, J. K. (1991). A History of Economics. London: Penguin Books

Galbraith, J. K. (1995.). Ekonomija u perspektivi. Zagreb: MATE

Gordon, B. (1975). Economic Analysis before Adam Smith. London and Basingstoke: Macmillan Press

Hirschberger, J. (1995.). Mala povijest filozofije. Zagreb: Školska knjiga

Jakšić, M., Praščević, A. (2007.). Istorija ekonomije, Beograd: Centar za izdavačku delatnost Ekonomskog fakulteta u Beogradu

Kale, E. (1990.). Povijest civilizacija. VI. izdanje, Zagreb: Školska knjiga

Kar, T. L. (1952.). O prirodi. II. izdanje, Zagreb: Matica hrvatska

Legradić, R. (1975.). Historija ekonomske teorije: otkrivanje zakona vrijednosti. Osijek: Štampa

Lunaček, V. (2004.). Povijest ekonomskih doktrina. Zagreb: Dom i svijet / Ekonomski fakultet

Mai, M. (2004.). Kratka povijest svijeta. Zagreb: Mozaik knjiga

Marković, M. (1984.). Istorija ekonomske misli. I. knjiga, Titograd: Univerzitetska riječ

Mesihović, S. (2015.). Orbis Romanvs. Sarajevo

Mesihović, S. (2011.). Revolucije stare Helade i Rimske Republike. Sarajevo: Filozofski fakultet u Sarajevu

Rima, I. H. (2001). Development of Economic Analysis. Sixth Edition, London: Routledge

Roll, E. (1956.). Povijest ekonomske misli. Zagreb: Kultura

Romac, A. (1973.). Izvori rimskog prava. Zagreb: Informator

Rozenberg, D. (1949.). Istorija političke ekonomije, prijevod s ruskog, Beograd

Sabolović, D. (1972.). Historija političke ekonomije. Zagreb: Informator

Sandmo, A. (2011). Economics Evolving: A History of Economic Thought, Princeton and Oxford: Princeton University Press

Schumpeter, J. A. (1975.). Povijest ekonomske analize. Zagreb: Informator

Seneka, L. A. (2007.). Dijalozi, Zagreb: Nova Akropola

Seneka, L. A. (2013.). Moralna pisma Luciliju. Svezak prvi, Zagreb: Demetra 
Sharma, S. (2010). Reflections on the Philosophical Foundations of Economics. Zagreb: Mikrorad

Spiegel, H. W. (1983). The Growth of Economic Thought. Durham, North Carolina: Duke University Press

Šoškić, B. (1988.). Ravoj i osnove savremene ekonomske misli. Beograd: Savremena administracija

van Beest, G. D. R. et al. (1974.). Velika ilustrirana povijest svijeta. Rijeka: Otokar Keršovani

Varro, M. T., De Re Rustica. Dostupno na: http://penelope.uchicago.edu/Thayer/E/ Roman/Texts/Varro/de_Re_Rustica/1*.html

Vejnović, N. (1966.). Historija filozofije. II. izdanje, Zagreb: Školska knjiga

Zakonik dvanaest ploča. (1994.). Prevod, uvod i komentar: Ante Romac, Zagreb: Latina et Graeca

\title{
ECONOMIC THOUGHT IN ANCIENT ROME
}

\author{
Summary
}

Unlike ancient Greece, in ancient Rome there was no developed economic thought. Most of the economic issues of interest to the scholars were pertinent to the field of agriculture. Great achievements in the field of law have provided the starting point for the further development of economic thought and analysis in the ancient Rome. The paper analyzes some of the direct impacts of the Law of the Twelve Tables (Leges duodecim tabularum) on the economy, and analyzes the contributions of eight writers and scholars in the consideration of economic issues: Marcus Porcius Cato Maior, Tiberius and Gaius Gracchus, Marcus Terentius Varro, Lucius Junius Moderatus Columella, Titus Lucretius Carus, Marcus Tullius Cicero, and Lucius Annaeus Seneca.

Key words: economic thought; law; patrician; plebeian, slave; economy; agriculture 